\title{
PENGEMBANGAN KOMPETENSI PROFESIONALISME GURU PAI DI ACEH
}

\author{
Zulfikar Ali Buto \\ Program Pascasarjana STAIN Malikussaleh \\ Jl. Medan-Banda Aceh Km. 275 No. 1, Lhokseumawe, 24352 \\ e-mail: zuale_lsm@yahoo.com
}

\begin{abstract}
Abstrak: Pengembangan kompetensi guru Pendidikan Agama Islam di wilayah Kota Lhokseumawe dilatarbelakangi oleh kompetensi guru Pendidikan Agama Islam mengalami kemunduran dari beberapa indikator profesionalisme. Artikel ini mengajukan temuan, yang didasarkan pada teknik pengumpulan data kualitatif yang dideskripsikan melalui analisis dekriptif, bahwa pengembangan kompetensi profesionalisme guru di Kota Lhokseumawe belum sepenuhnya mengalami perkembangan. Langkah-langkah pengembangan kompetensi profesionalisme guru adalah melalui belajar mandiri, mengikuti pelatihan individu, diskusi dan rapat dewan guru, melakukan penguatan melalui kegiatan Kerja Kelompok Guru, serta melakukan pusat kegiatan guru pada tingkat kecamatan. Lebih jauh ditemukan bahwa kendala utama pengembangan kompetensi profesionalisme guru adalah pelatihan guru berjalan di tempat, kurangnya alokasi dana peningkatan guru, terjadinya penurunan motivasi, dan kurangnya penguasaan informasi dan teknologi.
\end{abstract}

\begin{abstract}
The Development of Professionalism Competence of Islamic Education Teachers in Aceh. The development in Islamic Education Teachers Lhokseumawe City area, against the background by the competence of teachers of Islamic education suffered a setback of several indicators of professionalism. The findings based on qualitative data collection techniques are described through descriptive analysis reveals that the development of professional competencies of teachers in Lhokseumawe city has not shown significant growth. Efforts to develop professional competence of teachers are done through independent study, individual training, discussions and meetings of the board of teachers, strengthening through teachers' group work, and organizing centre for teachers' activities at the district level. However, the whole process of the training for teachers of Islamic education became stagnant, the budget cut for improving the quality of teachers, less motiveted, and lack of mastery of information and technology.
\end{abstract}

Kata Kunci: guru, kompetensi, profesionalisme, pendidikan agama Islam 


\section{Pendahuluan}

Pendidikan nasional yang berlandaskan Pancasila dan UUD 1945 berfungsi mengembangkan kemampuan dan membentuk watak serta peradaban bangsa yang bermartabat dalam rangka mencerdaskan kehidupan bangsa dan bertujuan untuk "mengembangkan potensi peserta didik agar menjadi manusia yang beriman dan bertakwa kepada Tuhan yang Maha Esa, berakhlak mulia, sehat, berilmu, cakap, kreatif, mandiri dan menjadi warga negara yang demokratis serta bertanggung jawab." Untuk mengemban fungsi tersebut pemerintah menyelenggarakan suatu sistem pendidikan sebagaimana tercantum dalam Undangundang Nomor 20 Tahun 2003 tentang Sistem Pendidikan Nasional (UU Disdiknas). Dalam pasal 11 ayat 1 , disebutkan bahwa pemerintah pusat dan pemerintah daerah harus menjamin terselenggaranya pendidikan yang bermutu bagi setiap warga negara. Terwujudnya pendidikan yang bermutu membutuhkan upaya yang terus menerus untuk selalu meningkatkan pendidikan yang kian terpuruk yang diakibatkan oleh berbagai faktor yang mempengaruhinya, salah satunya adalah kualitas guru tenaga pendidik.

Guru sangat menentukan keberhasilan pendidikan. Karena itu, dalam meraih keberhasilan tersebut diperlukan sosok guru yang ideal. Guru yang ideal harus menguasai kompetensi keguruan yang matang. Kompetensi tersebut merupakan perpaduan dari pengetahuan, keterampilan nilai dan sikap yang direfleksikan dalam kebiasaan berpikir dan bertindak. Demikian juga halnya dengan kompetensi yang harus dimiliki oleh guru pendidikan agama Islam (PAI). Kompetensi guru PAI yang dimaksud adalah pengembangan perpaduan dari pengetahuan, keterampilan nilai dan sikap yang direfleksikan dalam kebiasaan berpikir dan bertindak dalam menjalankan tugas dan fungsinya sebagai guru PAI. Bagi seorang guru dalam melaksanakan tugas dan fungsinya diperlukan kompetensi yang dapat membantu dan melengkapi aktivitasnya sebagai guru yang profesional. ${ }^{1}$ Guru yang dapat mengantarkan peserta didiknya atau dapat menjadikan orang lain pandai dalam ranah kognitif, afektif dan psikomotorik.

Seorang guru yang memiliki kompetensi berarti telah memiliki kemampuan untuk mewujudkan pendidikan yang direncanakan. Karenanya, ia harus memiliki sejumlah kemampuan yang meliputi kemampuan berpikir, kreatif dan komitmen untuk merealisasikan tujuan pembelajaran. Namun, tidak berhenti pada aspek tersebut di atas saja, guru juga dituntut memiliki kepedulian terhadap anak didik serta sosialnya, sehingga setiap tindak tanduknya adalah cerminan pribadi yang siap memberikan keteladanan bagi anak didiknya.

Kompetensi guru dalam perspektif yuridis disebutkan pada Peraturan Republik Indonesia Nomor 19 tahun 2005 tentang standar nasional pendidikan pasal 8 menyatakan bahwa pendidik harus memiliki kualifikasi akademik dan kompetensi sebagai agen pembelajaran, sehat jasmani, dan ruhani serta memiliki kemampuan untuk mewujudkan tujuan pendidikan

${ }^{1}$ Ngainun Naim, Menjadi Guru Inspiratif: Memberdayakan dan Mengubah Jalan Hidup Siswa (Yogyakarta: Pustaka Pelajar, 2009), h. 1-4. 
nasional. ${ }^{2}$ Selanjutnya, dalam Undang-udang No. 14 tahun 2005 tentang guru dan dosen Bab IV bagian satu tentang kualifikasi, kompetensi dan sertifikasi, pasal 10 menyatakan bahwa kompetensi guru sebagaimana dimaksud pada pasal 8 meliputi kompetensi kepribadian, kompetensi pedagogik, kompetensi sosial, dan kompetensi profesional yang diperoleh melalui pendidikan profesi. ${ }^{3}$

Realita yang terjadi berdasarkan hasil observasi awal di wilayah Kota Lhokseumawe, kini guru PAI telah banyak mengalami pergeseran dan pengalihan tugasnya yang menyebabkan kompetensi sebagaimana tersebut di atas terabaikan. Melalui observasi khususnya terhadap kompetensi profesional yang langsung berhubungan dengan proses pembelajaran masih terlihat kekurangannya, terutama dalam hal kemampuan pendidik dalam penguasaan materi pembelajaran secara luas dan mendalam terutama yang menyangkut dengan kompetensi guru PAI dalam bidang al-Qur'an hadis, fikih, akidah akhlak, dan SKI yang memungkinkannya membimbing peserta didik memperoleh kompetensi yang ditetapkan baik pada standar kompetensi maupun kompetensi dasar yang telah ditentukan sebelumnya.

Realita ini diperparah dengan kompetensi guru yang kurang mengintegrasikan kegiatan pembelajaran dalam kegiatan tugas dan fungsinya sebagai guru yang ideal. Daftar das sein kompetensi guru khususnya guru PAI di wilayah Kota Lhokseumawe dinilai belum mampu mengembangkan kompetensi dirinya baik kompetensi pedagogik, kepribadian, sosial, dan kompetensi profesional, sehingga belum dapat sepenuhnya mengintegrasikan pada tugas dan fungsinya dengan baik dan benar. Di sisi lain yang menjadi daftar masalah bagi kompetensi guru pendidikan agama Islam adalah berlakunya jam pelajaran wajib dengan beban tugas guru sertifikasi sejumlah 24 jam tanpa terkecuali. Pemenuhan jam wajib menjadi satu-satunya langkah bagi guru untuk terlepas dari tuntutan teoritis tanpa memperhatikan kualitas pembelajaran anak didiknya masing-masing. Paparan kondisi das sollen dan das sein memberikan pengaruh penting bahwa objek kajian tersebut sangat amat menarik dijadikan sebagai objek penelitian. Berdasarkan hasil diskusi terstruktur bersama rekan sejawat, pengamat pendidikan dan beberapa guru di wilayah Kota Lhokseumawe, masalah tersebut perlu dideskripsikan secara sistematis dan komprehensif guna mencari jalan keluar dan dapat membantu pengembangan kompetensi profesionalisme guru pendidikan agama Islam khususnya guru PAI yang bertugas pada Kementerian Agama Kota Lhokseumawe (Madrasah Ibtidaiyah, Madrasah Tsanawiyah, dan Madrasah Aliyah).

\section{Metode Penelitian}

Secara khusus, artikel ini akan mengkaji pengembangan kompetensi profesionalisme guru pendidikan agama Islam di Kota Lhokseumawe, Aceh. Artikel ini menggunakan h. 12.

${ }^{2}$ Syamsul Ma'arif, Guru Profesional Harapan dan Kenyataan (Semarang: Need's Press, 2011), ${ }^{3}$ Ibid. h. 134. 
penelitian kualitatif. Proses penelitian nantinya mencoba mendeskripsikan secara alamiah terhadap pengembangan kompetensi guru PAI dalam melaksanakan tugas dan tangung jawabnya sebagai guru agama Islam, serta mengupas dan menganalisis secara mendalam permasalahan yang terjadi pada lokasi penelitian yang sebenarnya. Selanjutnya, jika dilihat melalui pendekatannya, maka penelitian ini menggunakan pendekatan fenomenologi normatif konseptual. Pendekatan ini merupakan pendekatan yang berusaha memahami arti peristiwa dan kaitan-kaitannya terhadap konsep dan teori serta berusaha mencari dan menguraikan ciri-ciri permasalahan terhadap objek dan kejadian di lokasi penelitian. ${ }^{4}$

\section{Pengertian Kompetensi Profesionalisme Guru PAI}

\section{Kompetensi Guru}

Guru adalah pilar sebagai ujung tombak dalam upaya perubahan di masyarakat. Hal itu diasumsikan bahwa pendidikan dapat memengaruhi kehidupan dalam masyarakat. Seorang guru agama adalah orang yang mempunyai peran sentral dalam hal tersebut. Karena guru agama seharusnya mampu untuk melatih mental peserta didik menjadi terpuji dan mulia. Seorang guru PAI diharapkan mampu untuk menanamkan serta menumbuhkan keimanan yang kuat dan betul dalam diri peserta didik. Karena dengan keimanan keislaman seseorang akan baik sehingga menjadi manusia yang ihsan. Dalam hal ini, maka hendaknya seorang guru harus memiliki kemampuan atau kompetensi yang memadai. Pemerintah telah memberikan haluan dalam hal ini yakni pada UU Sistem Pendidikan Nasional No. 14 pasal 10 serta diterjemahkan ke dalam Permendiknas No. 16 Tahun 2007, yaitu guru harus memiliki kompetensi pedagogik, kepribadian, sosial, dan profesional.

Sebagai agen pembelajaran guru memiliki peran sentral dan cukup strategis antara lain sebagai fasilitator, motivator, pemacu, perekayasa pembelajaran, dan pemberi inspirasi belajar bagi peserta didik. ${ }^{5}$ Guru yang profesional pada intinya adalah guru yang memiliki kompetensi dalam melakukan tugas pendidikan dan pengajaran. Kompetensi merupakan suatu tugas yang memadai atas kepemilikan pengetahuan, keterampilan dan kemampuan yang dituntut oleh jabatan seseorang. ${ }^{6}$ Kompetensi juga berarti sebagai pengetahuan, keterampilan dan nilai-nilai dasar yang direfleksikan dalam kebiasaan berpikir dan bertindak. ${ }^{7}$

Namun, jika pengertian kompetensi guru tersebut dikaitkan dengan pendidikan agama Islam yakni pendidikan yang sangat penting bagi kehidupan manusia, terutama dalam mencapai ketentraman batin dan kesehatan mental pada umumnya. Agama Islam

${ }^{4}$ Lexy J. Moleong, Metode Penelitian Kualitatif (Bandung: Remaja Rosdakarya, 2001), h. 16.

${ }^{5}$ Trianto dan Titik Triwulan Tutik, Sertifikasi Guru dan Upaya Peningkatan Kualifikasi, Kompetensi dan Kesejahteraan (Jakarta: Prestasi Pustaka Publisher, 2007), h. 71.

${ }^{6}$ Roestiyah, Masalah-masalah Ilmu Keguruan, Cet. 6 (Jakarta: Bina Aksara,2001), h. 4.

${ }^{7}$ Kunandar, Guru Profesional: Implementasi Kurikulum Tingkat Satuan Pendidkan dan Sukses dalam Sertifikasi Guru (Jakarta: RajaGrafindo Persada, 2007), h. 52. 
merupakan bimbingan hidup yang paling baik, pencegah perbuatan salah dan munkar yang paling ampuh, dan pengendali moral yang tiada taranya. Kompetensi guru agama Islam adalah kewenangan untuk menentukan pendidikan agama Islam yang akan diajarkan pada jenjang tertentu di sekolah tempat guru itu mengajar. ${ }^{8}$

\section{Kompetensi Profesionalisme Guru PAI}

Untuk keberhasilan dalam mengemban peran sebagai guru, diperlukan adanya standar kompetensi. Berdasarkan UU Sisdiknas No. 14 tentang guru dan dosen pasal 10, menentukan bahwa kompetensi guru meliputi kompetensi pedagogik, kompetensi kepribadian, kompetensi profesional dan kompetensi sosial. Kompetensi profesional adalah kemampuan penguasaan materi pelajaran secara luas dan mendalam. ${ }^{9}$

Kompetensi profesional merupakan kemampuan penguasaan materi, pembelajaran secara luas dan mendalam yang memungkinkan membimbing peserta didik memenuhi standar kompetensi yang ditetapkan dalam standar nasional pendidikan. Adapun ruang lingkup kompetensi profesional. Pertama, mengerti dan dapat menerapkan landasan kependidikan baik filosofi, psikologis dan sosiologis. Kedua, mengerti dan dapat menerapkan teori belajar sesuai taraf perkembangan peserta didik. Ketiga, mampu menangani dan mengembangkan bidang studi yang menjadi tanggung jawabnya. Keempat, mengerti dan dapat menerapkan metode pembelajaran yang bervariasi. Kelima, mampu mengembangkan dan menggunakan berbagai alat, media dan sumber belajar yang relevan. Keenam, mampu mengorganisasikan dan melaksanakan program pembelajaran. Ketujuh, mampu melaksanakan evaluasi hasil belajar peserta didik. Kedelapan, mampu menumbuhkan kepribadian peserta $\operatorname{didik}^{10}$

\section{Landasan Kompetensi Profesionalisme Guru}

Menurut Undang-Undang Repulik Indonesia No. 14/2005 Pasal 1 ayat 4, profesional adalah pekerjaan atau kegiatan yang dilakukan oleh seseorang dan menjadi sumber penghasilan kehidupan yang memerlukan keahlian, kemahiran, atau kecakapan yang memenuhi standar mutu atau norma tertentu serta memerlukan pendidikan profesi. Guru merupakan keterampilan profesional yang untuk menyandang profesi tersebut harus menempuh jenjang pendidikan tinggi pada program studi kependidikan. ${ }^{11}$

\footnotetext{
${ }^{8}$ Zakiyah Daradjat, Pendidikan Islam dalam Keluarga dan Sekolah, Cet. 2 (Jakarta: Ruhama,1995), h. 95 .

${ }^{9}$ Asrorun Ni'am, Membangun Profesionalitas Guru (Jakarta: eLSAS, 2006), h. 199.

${ }^{10}$ Mulyasa, Standar Kompetensi Sertifikasi Guru (Bandung: Remaja Rosdakarya, 2007), h. $135-136$.

${ }^{11}$ Mohamad Ali , Pengembangan Kurikulum di Sekolah (Bandung: Sinar Baru, 1998), h. 31-34.
} 
Dalam Undang-Undang Republik Indonesia Nomor 14 Tahun 2005 tentang Guru dan Dosen, dikemukakan bahwa profesional guru merupakan bidang pekerjaan khusus yang dilaksanakan berdasarkan prinsip yaitu memiliki bakat, minat, panggilan jiwa dan idealisme, memiliki komitmen untuk meningkatkan mutu pendidikan, keimanan, ketakwaan, dan akhlak mulia, memiliki kualifikasi akademik dan latar belakang pendidikan sesuai dengan bidang tugas, memiliki kompetensi yang diperlukan sesuai dengan bidang tugas, memiliki tanggung jawab atas pelaksanaan tugas keprofesionalan, memperoleh penghasilan yang ditentukan sesuai dengan prestasi kerja, memiliki kesempatan untuk mengembangkan profesionalisme secara berkelanjutan dengan belajar sepanjang hayat, memiliki jaminan perlindungan hukum dalam melaksanakan tugas profesionalisme, dan memiliki organisasi profesi yang mempunyai kewenangan mengatur hal-hal yang berkaitan dengan tugas keprofesionalan. ${ }^{12}$

\section{Tugas dan Tanggung Jawab Guru PAI}

Tugas guru sebagai profesi meliputi mendidik, mengajar, dan melatih. Mendidik berarti meneruskan dan mengembangkan nilai-nilai hidup, mengajar berarti meneruskan dan mengembangkan ilmu pengetahuan dan teknologi, sedangkan melatih berarti mengembangkan keterampilan-keterampilan pada peserta didik. Dengan kata lain, seorang guru dituntut mampu menyelaraskan aspek kognitif, afektif, dan psikomotorik dalam proses pembelajaran. ${ }^{13}$

Hal ini sejalan dengan yang diamanatkan dalam Pasal 1 ayat 1 UU RI No. 14/2005 tentang guru dan dosen, di mana seorang guru adalah pendidik profesional dengan tugas utama mendidik, mengajar, membimbing, mengarahkan, melatih, menilai, dan mengevaluasi peserta didik pada jalur pendidikan formal, pendidikan dasar, dan pendidikan menengah. Pada tingkat pelaksanaan pembelajaran di kelas, guru lah yang sangat berperan dalam membawa peserta didiknya ke arah pembelajaran yang diisyaratkan dalam kurikulum.

\section{Tugas Guru PAI}

Tugas pendidik dalam proses pembelajaran secara berurutan adalah menguasai mata pelajaran, menggunakan metode pembelajaran agar peserta didik mudah menerima dan memahami pelajaran, melakukan evaluasi pendidikan yang dilakukan, dan menindak lanjuti hasil evaluasinya. ${ }^{14}$

Ahmad Tafsir menjelaskan bahwa tugas seorang guru adalah mendidik. Yang paling utama dari sekian tugas guru adalah mengajar dan semua tugas yang berhubungan dengan

\footnotetext{
${ }^{12}$ UU Republik Indonesia Nomor 14 Tahun 2005 tentang Guru dan Dosen.

${ }^{13}$ Umardi, Pembinaan Profesionalisme Tenaga Kependidikan (Jakarta: Depdikbud Dirjen Dikti, 1999), h. 10.

${ }^{14}$ Ibid, h. 51.
} 
pencapaian tujuan pengajaran. Tugas guru dapat dirincikan sebagai berikut: membuat persiapan mengajar, mengajar, dan mengevaluasi hasil pengajaran. Setelah tugas ini jelas dan dilaksanakan dengan baik, barulah guru dituntut melaksanakan tugas tugas mendidik yang lainnya. ${ }^{15}$

Selanjutnya, Imam al-Ghazâlî mengemukakan bahwa, tugas pendidik yang utama adalah menyempurnakan, membersihkan, mensucikan, serta membawa hati manusia (peserta didik) untuk taqarrub ila Allâh (mendekatkan diri kepada Allah). Dalam pandangan Islam, secara umum guru juga bertugas mendidik, yaitu mengupayakan seluruh potensi anak didik yang meliputi potensi kognitif, afektif, dan psikomotorik. ${ }^{16}$

Sama dengan teori pendidikan Barat, tugas pendidik dalam pandangan Islam secara umum adalah mendidik, yaitu mengupayakan perkembangan seluruh potensi peserta didik, baik potensi psikomotorik, kognitif, maupun afektif. Perbedaannya bukan pada tugas yang dilaksanakan, tetapi pada filsafat yang dianut sistem filsafat Barat memang berbeda dengan sistem filsafat Muslim. ${ }^{17}$

\section{Tanggung Jawab Guru PAI}

Tanggung jawab guru dalam pendidikan Islam merupakan suatu kondisi wajib menanggung segala sesuatu sebagai akibat dari keputusan yang diambil atau tindakan yang dilakukan (apabila terjadi sesuatu dapat disalahkan). ${ }^{18}$ Tanggung jawab juga dapat diartikan sebagai suatu kesediaan untuk melaksanakan dengan sebaik baiknya terhadap tugas yang diamanatkan kepadanya dengan kesediaan menerima segala konsekuensinya. ${ }^{19}$

Guru adalah pekerja profesional yang secara khusus dipersiapkan untuk mendidik anak-anak yang telah diamanatkan orang tua untuk dapat mendidik anaknya di sekolah. Guru atau pendidik sebagai orangtua kedua dan sekaligus penanggung jawab pendidikan anak didiknya setelah kedua orangtua di dalam keluarganya memiliki tanggung jawab pendidikan yang baik kepada peserta didiknya. Dengan demikian apabila orang tua menjadi penanggung jawab utama ketika anak anak berada di luar sekolah, guru merupakan penanggung jawab utama anak-anak melalui proses pendidikan formal anak yang berlangsung di sekolah karena tanggung jawab merupakan konsekuensi logis dari sebuah amanat yang dipikulkan di atas pundak para guru. ${ }^{20}$

${ }^{15}$ Ahmad Tafsir, Ilmu Pendidikan Islam (Bandung: Remaja Rosdakarya, 2002), h. 135-136.

${ }^{16} \mathrm{M}$. Zainuddin, Pendidikan Islam dari Paradigma Klasik hingga Kontemporer (Malang: UIN Malang Press, 2009), h. 167.

${ }^{17}$ Tafsir, Ilmu Pendidikan Islam, h. 126.

${ }^{18}$ Barnawi Novan Ardi Wiyani, Ilmu Pendidikan Islam (Jogjakarta: Ar-Ruzz Media, 2012), h. 97.

${ }^{19}$ Ibid.

${ }^{20} \mathrm{Ibid}$. 
Bagi guru pendidikan agama Islam (PAI) tugas dan kewajiban sebagaimana yang dikemukakan di atas merupakan amanat yang diterima oleh guru atas dasar pilihannya untuk memangku jabatan guru. Amanat tersebut wajib dilaksanakan dengan penuh tanggung jawab. Allah SWT. berfirman, sesungguhnya Allah menyuruh kamu menyampaikan amanat kepada yang berhak menerimanya, dan (menyuruh kamu) apabila menetapkan hukum di antara manusia supaya kamu menetapkan dengan adil. Sesungguhnya Allah memberi pengajaran yang sebaik-baiknya kepadamu. Sesungguhnya Allah adalah Maha mendengar lagi Maha Melihat (Q.S. al-Nisâ'/4: 58). Tanggung jawab guru pendidikan agama Islam terhadap amanatnya sebagai mana dikemukakan di atas, tegasnya diwujudkan dalam upaya mengembangkan profesionalismenya, yaitu mengembangkan mutu, kualitas dan tindak tanduknya. ${ }^{21}$

Tanggung jawab guru ialah keyakinannya bahwa setiap tindakannya dalam melaksanakan tugas dan kewajiban didasarkan atas pertimbangan professional secara tepat. Pekerjaan guru menuntut kesungguhan dalam berbagai hal. Karenanya, posisi dan persyaratan para "pekerja pendidikan" atau orang-orang yang disebut pendidik karena pekerjaan ini patut mendapat pertimbangan dan perhatian yang sungguh sungguh pula. Pertimbangan tersebut dimaksudkan agar usaha pendidikan tidak jatuh kepada orang-orang yang bukan ahlinya, yang dapat megakibatkan banyak kerugian.

\section{Hasil dan Pembahasan}

Melalui pengumpulan data yang diorganisir dengan baik berdasarkan observasi, wawancara, dan dokumentasi pada wilayah kota Lhokseumawe dapat dideskripsikan pengembangan kompetensi profesionalisme guru dalam melaksanakan tugas dan tanggung jawabnya sebagai guru adalah sebagai berikut. Guru merupakan faktor yang sangat dominan dan paling penting dalam pendidikan, untuk mencapai tujuan pembelajaran di madrasah. Kemampuan guru dalam mengajar, proses pembelajaran dan dalam mencapai tujuan pendidikan merupakan indikator keberhasilan proses belajar mengajar siswa. Agar dalam melaksanakan tugasnya secara baik sesuai dengan profesi yang dimilikinya, guru perlu menguasai berbagai hal sebagai kompetensi yang dimilikinya.

Profesional guru merupakan suatu kemampuan guru dalam mengelola dirinya sendiri dalam melaksanakan tugas dan fungsinya sehari-hari secara profesional dengan sebaikbaiknya. Kedudukan guru sebagai tenaga profesional mengandung arti bahwa pekerjaan guru hanya dapat dilakukan oleh seorang yang mempunyai kualifikasi akademik, kompetensi, dan sertifikat pendidik sesuai dengan persyaratan untuk setiap jenis dan jenjang pendidikan tertentu. Sedangkan kompetensi guru adalah suatu kemampuan tertentu yang dimiliki guru dalam proses pembelajaran. Guru sebagai tenaga profesional harus memiliki empat kompetensi, yaitu kompetensi pedagogik, kompetensi profesional, kompetensi sosial, dan kompetensi kepribadian.

\footnotetext{
${ }^{21} \mathrm{Ibid}$. h. 5
} 
Kompetensi diartikan sebagai pengetahuan, keterampilan, dan nilai-nilai dasar yang direfleksikan dalam kebiasaan berpikir dan bertindak, spesifikasi dari pengetahuan, keterampilan, dan sikap yang dimiliki seseorang serta penerapannya di dalam pekerjaan, sesuai dengan standar kinerja yang dibutuhkan oleh lapangan. Perlu disadari bersama bahwa kompetensi yang dimiliki oleh setiap guru akan menunjukkan kualitas guru yang sebenarnya, terwujud dalam bentuk penguasaan pengetahuan, keterampilan maupun sikap profesional dalam menjalankan fungsi sebagai guru. Guru-guru yang profesional adalah guru-guru yang memiliki perhatian lebih terhadap pengembangan dirinya dan peserta didik, sehingga kinerjanya dapat meningkatakan kualitas tanggung jawabnya terhadap profesinya dari aktivitas pribadinya di luar pendidikan. Berikut alternatif pengembangan kompetensi profesionalisme guru bidang studi rumpun pendidikan agama Islam yang diinternalisasikan sesuai dengan kebutuhan daerah masing-masing.

\section{Pengembangan Kompetensi Guru PAI di Kota Lhokseumawe}

Pengembangan kompetensi profesionalisme guru PAI di wilayah Kota Lhokseumawe dideskripsikan melalui indikator profesionalisme guru sebagai berikut.

\section{Pengembangan Landasan Filosofis, Psikologis, dan Sosiologis Pendidikan Guru PAI}

Internalisasi nilai-nilai filsafat dalam pembelajaran adalah memberikan inspirasi bagaimana mengorganisasikan proses pembelajaran yang ideal. Teori pendidikan bertujuan menghasilkan pemikiran tentang kebijakan dan prinsip-prinsip pembelajaran yang didasari oleh filsafat pembelajaran. Berdasarkan observasi mendalam di wilayah Kota Lhokseumawe khususnya pada madrasah-madrasah di bawah Kementerian Agama Kota Lhokseumawe mengindikasikan bahwa sebagian kecil sudah menggunakan landasan filsafat sebagai acuan berpijak dalam proses pembelajaran. Para guru yang mengajar pada madrasahmadrasah sebagian kecil telah menjadikan landasan filsafat sebagai acuan pengembangan pembelajaran yang menuai kegiatan pembelajaran yang berjalan dengan baik.

Indikator internalisasi landasan filsafat sebagai acuan dalam kegiatan pembelajaran selama ini dinilai melalui kecintaan para guru terhadap tugas dan tanggung jawabnya sebagai seorang pendidik. Akan tetapi sebagian besar cukup menarik dan perlu dituangkan adalah para guru yang mengajar di bawah Kementerian Agama relatif belum sepenuhnya memiliki kecintaannya pada profesinya sebagai seorang pendidik. Sebagaimana yang ditemukan di lapangan para guru belum sepenuhnya merasa menjiwai seorang guru yang hakiki, menjadikan profesi guru sebagai sampingan atau dinomor duakan dengan hal lainnya. Guru lebih memilih meninggalkan tugasnya dengan hal-hal pribadi seperti berjualan, bisnis marketing, arisan keluarga, memanen hasil kebun serta sawah, bahkan adapula yang rela meninggalkan tugasnya karena bepergian urusan pribadi ke luar kota. 
Indikasi lainnya yang menunjukkan bahwa landasan filsafat belum sepenuhnya diinternalisasikan serta dikembangkan dengan baik oleh para guru di wilayah Kota Lhokseumawe khususnya di bawah Kementerian Agama adalah pada semangat menjiwai profesinya sebagai seorang guru. Semangat mengajar serta melaksanakan pembelajaran sering diartikan sebagai rutinitas yang menyulitkan suasana belajar menjadi vakum dan terjadi dengan proses alamiah, sehingga kondisi pembelajaran sulit terkontrol oleh guru yang berakibat proses pembelajaran terlewatkan begitu saja tanpa adanya daya dan upaya untuk menyelamatkan waktu yang efektif dan efesien.

Pengembangan landasan psikologis diartikan sebagai pengembangan nilai-nilai kejiwaan interaksi edukasi antara guru dengan peserta didiknya. Berdasarkan observasi mendalam terhadap subjek penelitian ini, tim berusaha menjajakinya melalui gejala interaksi edukatif yang terjalin melalui aktivitas belajar di dalam kelas dan di luar kelas. Berdasarkan interaksi edukatif dalam berkomunikasi keduanya saling memahami satu dengan lainnya. Demikian halnya pada saat bimbingan dan arahan yang diberikan kepada siswa yang mengalami kesulitan belajar para guru mampu mengontrol diri dengan baik sehingga bimbingan konseling terhadap siswa berjalan dengan baik.

Untuk pengembangan landasan psikologis dalam kegiatan pembelajaran selama ini para dewan guru mengalami kesulitan khususnya pada kelas V dan VI, seiring dengan perkembangan anak serta pengaruh lingkungan yang terus mengalami kemajuan para guru pun kesulitan membendung perkembangan anak. Dewan guru mengalami kesulitan untuk melakukan bimbingan serta arahan berdasarkan teori psikologi yang ada, sehingga bimbingan dan arahan yang diberikan oleh guru-guru selama ini lahir dan berkembang secara alami sesuai dengan kebutuhan anak.

Selanjutnya indikator pengembangan profesionalisme guru adalah pengembangan landasan sosiologis dalam pembelajaran guru madrasah di Kota Lhokseumawe. Berdasarkan observasi dalam beberapa waktu dalam kegiatan pembelajaran di beberapa madrasah Kota Lhokseumawe menunjukkan bahwa landasan sosiologi pembelajaran belum sepenuhnya dikembangkan oleh para guru-guru. Kata kunci dalam dimensi kesosialan manusia adalah komunikasi dan kebersamaan. Namun dalam kenyataannya, model pembelajaran yang diterapkan belumlah mengakomodir komunikasi dan kebersamaan secara optimal. Modelmodel pembelajaran yang banyak digunakan dalam pendidikan saat ini hanyalah model pembelajaran di dalam ruangan saja, tidak lebih dari itu, sehingga kemudian komunikasi dan kebersamaan yang terjadi hanyalah antara guru dengan murid dan dengan sesama murid.

Pertama kali dideskripsikan temuan dalam kegiatan pembelajaran yang bertolak belakang dengan landasan sosiologis dalam pembelajaran. Interaksi tidak seimbang serta kerja sama para guru dan murid belum dijadikan ajang penguat hubungan harmonis antara mereka, sehingga kerjasama antara keduanya masih tataran perintah dan intruksi dari atas ke bawah, bukan karena adanya saling membutuhkan antara satu dengan lainnya. 
Kedua dideskripsikan temuan di luar kegiatan pembelajaran, ternyata pengembangan landasan sosiologis di luar pembelajaran cukup sangat tidak menyenangkan. Hampir semua madrasah mengalami kondisi yang berubah dari tradisi dan kebudayaan Aceh di Kota Lhokseumawe, para guru kurang mampu melakukan interaksi sosial dengan lingkungan dan masyarakat sekitar. Sosialitas guru terhadap kondisi dan kejadian sekeliling menjadi salah dilema, diperparah lagi dengan minimnya guru-guru yang saling bersilaturahmi dengan orang tua atau peserta didiknya yang sudah lama tidak masuk sekolah dan tanpa ada berita ke pihak keluarga sehingga anak dinyatakan sudah keluar tanpa berita yang jelas.

\section{Pengembangan Teori Belajar Guru}

Secara praktis, teori belajar dapat dipahami sebagai prinsip umum atau kumpulan prinsip yang saling berhubungan dan merupakan penjelasan atas sejumlah fakta dan penemuan yang terkait dengan peristiwa belajar. Pengembangan teori belajar dalam pembelajaran dilakukan agar aktivitas yang dilakukan guru dalam proses pembelajaran terarah pada upaya peningkatan potensi siswa secara komprehensif, maka pembelajaran harus dikembangkan sesuai dengan prinsip-prinsip yang benar, yang bertolak dari kebutuhan internal siswa untuk belajar.

Hasil observasi yang dilakukan beberapa madrasah di Kota Lhokseumawe menunjukkan beberapa gejala negatif. Gejala negatif yang dimaksud adalah para guru belum sepenuhnya mampu menjadikan proses pembelajaran sebagai ajang memberikan stimulus kepada peserta didik untuk dapat belajar secara mandiri sehingga menemukan jati diri mereka yang sesungguhnya. Para guru belum terampil melakukan kegiatan apersepsi pada saat membuka pelajaran sehingga peserta didik belum memiliki rangsangan positif terhadap materi yang akan diajarkan. Selain itu, para guru masih kesulitan memberikan free test dan post test di setiap proses pembelajaran akibatnya proses pembelajaran tidak dapat diukur keberhasilannya dengan baik. Fakta temuan melalui observasi dan wawancara di beberapa Madrasah Kota Lhokseumawe menunjukkan bahwa guru belum bisa membedakan teori belajar, pendekatan pembelajaran, strategi pembelajaran, dan metode pembelajaran sehingga pembelajaran berjalan sebagaimana biasa saja.

\section{Pengembangan Bidang Studi Guru}

Pengembangan bidang studi merupakan pemahaman mendalam, analisis kebutuhan mendalam, mengaplikasikan secara mendalam serta mampu menciptakan hal-hal yang baru dari sesuatu yang sedang dipelajari. Tahap pengembangan bidang studi adalah tahap di mana seorang guru mampu menciptakan suasana kondusif peserta didik jauh lebih tahu dari apa yang diketahui gurunya.

Pengembangan bidang studi ada baiknya terdokumentasikan dengan baik namun dapat pula tidak terdokumentasikan. Artinya, pengembangan bidang studi dapat disajikan 
secara tertulis dapat pula tanpa tertulis dalam dokumentasi guru bersangkutan. Pengembangan bidang studi merupakan kreativitas serta wawasan guru yang diperoleh melalui kompetensi pedagogik yang berkualitas. Inilah inti daripada kurikulum 2013 untuk pembelajaran tematik pada sistem pembelajaran tema-tema tertentu. Guru cukup mengajarkan tematema tersebut dengan mengembangkannya sesuai dengan kebutuhan dan penjabaran studi-studi tertentu sehingga ketiga ranah pembelajaran kognitif, afektif, dan psikomotorik tercapai dengan baik dan sempurna.

\section{Pengembangan Metode Pembelajaran Guru}

Indikator pengembangan kompetensi profesionalisme lainnya adalah pengembangan metode pembelajaran guru di Kota Lhokseumawe. Untuk bidang pengembangan metode pembelajaran, beberapa guru di madrasah yang berbeda, menunjukkan bahwa kemampuan guru-guru dalam menggunakan metode sesuai dengan materi yang diajarkan sudah relevan. Penggunaan metode serta dikreasikan dengan strategi lalu dikuatkan dengan teknik menjadikan proses pembelajaran jauh lebih baik.

\section{Pengembangan Media dan Sumber Pembelajaran Guru}

Pengembangan media pembelajaran merupakan pengembangan alat bantu yang dilakukan oleh para guru untuk memudahkan proses pembelajaran sehingga tujuan pembelajaran tercapai sesuai dengan yang diharapkan. Artinya, media pembelajaran adalah segala sesuatu yang dapat digunakan untuk menyalurkan pesan pendidikan dari pengirim (guru) ke penerima (siswa) yang dapat merangsang pikiran, perasaan, perhatian, dan minat siswa sehingga dapat mendorong terjadinya proses belajar pada diri penerima pesan (siswa). Sedangkan media pembelajaran bagi guru rumpun bidang studi pendidikan agama Islam (PAI) adalah segala sesuatu yang dapat digunakan untuk menyalurkan pesan pendidikan agama Islam dari guru kepada siswa yang dapat merangsang pikiran, perasaan, perhatian, dan minat siswa sehingga dapat mendorong terjadinya proses belajar pada diri siswa.

Melalui observasi dalam berbagai kegiatan pembelajaran di Kota Lhokseumawe menunjukkan bahwa penggunaan dan pengembangan media pembelajaran relatif belum memadai. Indikasi yang menunjukkan bahwa belum dikembangkannya media pembelajaran guru bidang studi rumpun pendidikan agama Islam belum sepenuhnya menggunakan media hasil karyanya masing-masing. Penggunaan media masih relatif pada hal-hal yang konsumtif sesuai dengan media yang sudah umum digunakan selama ini. Contoh penggunaan media gambar, penggunaan media karton, penggunaan media LCD atau proyektor dan media tulis. Penggunaan media tulis sering digunakan pada pembelajaran al-Qur'an hadis, akidah akhlak, dan sejarah kebudayaan Islam. Sedangkan sesekali media elektronik seperti tipe atau sejenisnya digunakan pada pembelajaran al-Qur'an khususnya standar kompetensi membaca al-Qur'an. 


\section{Pengembangan Pengelolaan dan Program Kelas Guru}

Pengelolaan kelas berbeda dengan pengelolaan pembelajaran. Pengelolaan pembelajaran lebih menekankan pada kegiatan perencanaan, pelaksanaan, evaluasi dan tindak lanjut dalam suatu pembelajaran. Sedangkan pengelolaan kelas lebih berkaitan dengan upayaupaya untuk menciptakan dan mempertahankan kondisi yang optimal bagi terjadinya proses belajar yang memberi bimbingan terhadap perilaku peserta didik yang menyeleweng pada perhatiannya di kelas, pemberian ganjaran, penyelesaian tugas oleh peserta didik secara tepat waktu, penetapan norma kelompok yang produktif di dalamnya mencakup pengaturan orang (peserta didik) dan fasilitas. Pengelolaan kelas dilakukan untuk mendukung terjadinya proses pembelajaran yang lebih berkualitas. Oleh karena itu, pendekatan atau teori apapun yang dipilih dan yang dijadikan dasar dalam pengelolaan kelas, harus diorientasikan pada terciptanya proses pembelajaran secara aktif dan produktif.

Teknik pengelolaan kelas harus diupayakan agar tidak mengganggu aspek pembelajaran dalam pelajaran. Bila direncanakan dengan baik melalui RPP, pembelajaran akan terlaksana dengan cepat dan lancar dari satu kegiatan ke kegiatan lainnya (dari RPP ke 1 ke RPP berikutnya). Untuk melihat deskripstif pengembangan pengelolaan kelas guru bidang studi rumpun pendidikan agama Islam (PAI) di bawah Kementerian Agama Kota Lhokseumawe dapat dianalisis dengan menetapkan aturan kelas. Menetapkan peraturan kelas sangat dibutuhkan untuk terlaksananya proses pembelajaran yang tertib dan bersih. Sebagai hal yang dibutuhkan di beberapa madrasah di wilayah Kota Lhokseumawe telah melakukan serta menetapkan hal tersebut sebagai langkah untuk dapat menertibkan lingkungan sekolah serta ruang kelas yang memenuhi standar pembelajaran yang baik. Melalui observasi yang dilakukan oleh tim peneliti terhadap beberapa madrasah dalam menetapkan aturan kelas yang baik dengan beberapa langkah. Pertama, melalui surat edaran kepala madrasah (sekolah), menuliskan beberapa slogan ketertiban kelas dan madrasah dengan majalah dinding, dan papan tulis, dan tempelan kertas pada setiap ruang kelas.

Kedua, memulai kegiatan tepat waktu. Kegiatan pembelajaran pada madrasah wilayah Kota Lhokseumawe beberapa guru yang mengajar belum tepat waktu sesuai dengan jam yang telah ditetapkan. Ketidaktepatan waktu khususnya terjadi pada saat pergantian jam pembelajaran berlangsung, seringnya guru menunggu dan menghabiskan waktu menunggu pergantian jam pembelajaran sehingga waktu yang seharusnya masuk mengalami keterlambatan 15 sampai 20 menit setiap jam pembelajarannya.

Ketiga, membuka pembelajaran. Kegiatan membuka pembelajaran dalam pendahuluan yang terbiasa dengan kegiatan salam, apersepsi, dan free test merupakan langkah yang wajib dilaksanakan oleh setiap guru dengan berbagai bidang studinya masing-masing. Kemampuan guru dalam melakukan apersepsi pada setiap bidang studi rumpun pendidikan agama Islam dinilai belum memenuhi kriteria pembelajaran yang baik. Indikasinya adalah guru-guru kurang mampu melakukan stimulus pembelajaran sebelumnya untuk membuka pembelajaran yang baru. 
Keempat, mengatur pelajaran. Pengaturan atau pengorganisasian bahan ajar oleh seorang guru merupakan langkah untuk merelepansikan bahan ajar dengan kemampuan peserta didik masing-masing. Untuk kurikulum 2013 khususnya bidang studi rumpun pendidikan agama Islam nilai telah melakukan pengorganisasian bahan ajar dengan baik dan tersruktur. Namun demikian karena buku tema yang disediakan oleh pemerintah belum tersalurkan pada setiap madrasah, maka pihak sekolah sampai penelitian ini selesai masih menggunakan buku paket Kurikulum Tingkat Satuan Pendidikan (KTSP), sehingga pengaturan dan pengorganisasian bahan ajar berjalan dengan baik.

Kelima, pengelompokkan siswa. Memperkaya metode pembelajaran guru pada madrasah salah satunya adalah metode kooperatif antar siswa dengan siswa lainnya. Penggunaan kelompok serta persentase penggunaannyapun relatif lebih sering dilakukan pada setiap pembelajaran berlangsung. Untuk itu berdasarkan observasi yang dilakukan beberapa guru bidang studi rumpun pendidikan agama Islam penggunaan pengelompokan siswa paling sering dilakukan.

Keenam, tata ruang dan duduk kelas (denah). Penguasaan tata ruang dan duduk kelas peserta didik yang nyaman dan menyenangkan merupakan indikator profesionalisme seorang guru yang harus diperhatikan dengan baik. Tata ruang termasuk tata duduk peserta didik merupakan cerminan kesiapan guru dan peserta didik untuk memulai pembelajaran tertentu. Selama melakukan observasi pada setiap pembelajaran guru bidang studi rumpun pendidikan agama Islam selama ini guru relatif masih menggunakan sistem tata ruang Tut Wuri Handayani (murid di belakang guru di depan). Tata ruang masih menggunakan persegi empat memenuhi ruangan yang tersedia dengan berbagai kekurangan yang ada.

Ketujuh, memberi penilaian hasil belajar. Salah satu kewajiban seorang guru setelah melakukan proses pembelajaran adalah melakukan evaluasi serta memberikan penilaian dari hasil evaluasi yang diberikan. Pemberian nilai hasil evaluasi bertujuan untuk melihat serta merefleksikan penguasaan, kemampuan, serta pengetahuan yang telah diikuti peserta didik selama belajar. Untuk itu guru dituntut dapat melakukan evaluasi serta memberi penilaian yang objektif bukan subjektif. Pemberian nilai yang obektif adalah pemberian nilai menurut kemampuan dan penguasaan siswa tanpa melihat latar belakang siswa serta menghilangkan indikasi pilih kasih antar peserta didik. Selama melakukan observasi serta cek dokumentasi hasil penilaian peseta didik selama ini sudah tergolong sangat rapi dan baik. Indikasinya adalah sistem penilaian yang diberikan oleh guru pada madrasah wilayah Kota Lhokseumawe telah mengikuti petunjuk dan teknis evaluasi yang baik dan benar, sehingga pemberian nilai berjalan dengan baik. Akan tetapi, temuan lain yang selama ini para guru merasa kesulitan membedakan serta menyatukan nilai antara kognitif, afektif, dan psikomotorik dalam per semester atau per catur wulan.

Kedelapan, mengakhiri pelajaran. Kegiatan mengakhiri atau menutup pelajaran dilakukan setelah aktivitas pembelajaran akan berakhir, maka seorang guru dituntut melakukan kesimpulan, motivasi, memberikan gambaran pada pertemuan berikutnya, dan memberi 
salam. Sejauh temuan yang diperoleh terhadap kegiatan penutupan pembelajaran pada guru-guru bidang studi rumpun pendidikan agama Islam selama ini telah memadai. Kegiatan penutupan dilakukan dengan berbagai teknik yang menarik peserta didik untuk menyimpulkan sub pokok bahasan yang telah dipelajarinya serta mendapat stimulus akhir sebelum pembelajaran ditutup.

\section{Pengembangan Evaluasi Pembelajaran Guru}

Pengembangan evaluasi pembelajaran guru bidang studi rumpun pendidikan agama Islam (PAI) di Kota Lhokseumawe merupakan langkah yang ditempuh guru untuk sistem evaluasi yang terukur dan terencana dengan benar. Sebagai seorang guru yang profesional dalam bidang studinya menaruh harapan besar pada sistem evaluasi yang dilakukan adalah sistem evaluasi yang terdiri atas komponen penilaian yang sistematis dan mampu mengakomodir semua ranah pendidikan seperti ranah kognitif, ranah afektif, dan ranah psikomotorik.

Pengembangan evaluasi guru diharapkan melakukan dalam beberapa komponen di antaranya adalah melakukan analisis kebutuhan melalui pokok bahasan yang diajarkan. Untuk bidang ini para guru madrasah belum sepenuhnya melaksanakan dengan terstruktur akan tetapi secara individual dilakukan juga dengan cara refleksi pembelajaran sebelum melakukan evaluasi. Komponen berikutnya adalah pengembangan pendekatan program pembelajaran yang berupa refleksi terhadap in put, proses, dan out put pembelajaran sehingga tujuan pembelajaran dapat terukur dengan baik dan benar. Untuk komponen ini melalui pendalaman obeservasi para guru yang telah melakukan evaluasi sangat jarang melakukan refleksi terhadap input, proses dan output pembelajaran. Hal ini terindikasi melalui bentuk dan jenis soal yang terkesan hanya melakukan evaluasi dengan fomalitas saja untuk mendapatkan nilai para peserta didik.

Pengembangan evaluasi guru madrasah di wilayah Kota Lhokseumawe adalah pendekatan pengembangan hasil belajar yang memiliki unsur-unsur, di antaranya adalah guru telah menentuan tujuan penilaian, guru mengidentifikasi hasil belajar, menyusun kisi-kisi evaluasi, guru menyusun draf instrumen evaluasi, dan guru melakukan uji coba dan analisis butir soal yang diberikan ke pesarta didiknya. Berdasarkan observasi dari beberapa unsur pengembangan evaluasi guru-guru bidang studi rumpun Pendidikan Agama Islam (PAI) di wilayah Kota Lhokseumawe menunjukkan bahwa hal yang sulit dikembangkan oleh guru-guru dalam melaksanakan evaluasi adalah pengembangan butir instrumen soal yang terkadang membuat butir soal dengan satu jenis insturmen saja.

Dengan demikian, ditemukan tim mengenai pengembangan kompetensi profesionalisme guru bidang studi rumpun Pendidikan Agama Islam (PAI) pada madrasah dalam melaksanakan tugas dan tanggung jawabnya sebagai seorang guru belum sepenuhnya terlaksana dengan baik. Sebagai seorang guru yang profesional tugasnya sebagai seorang guru bertanggung jawab terhadap terlaksananya proses pembelajaran yang baik dalam berbagai komponen 
yang ada. Untuk menunjang profesionalisme seorang guru dapat pula ditemukan pada terlaksananya tugas dan tanggung jawabnya dalam proses pembelajaran.

Pengembangan kompetensi profesionalisme guru pendidikan agama Islam di wilayah Kota Lhokseumawe dilaksanakan melalui berbagai strategi dalam bentuk pendidikan dan pelatihan (diklat) maupun bukan diklat. Pertama, pelatihan dalam bentuk IHT adalah pelatihan yang dilaksanakan secara internal di kelompok kerja guru, sekolah atau tempat lain yang ditetapkan untuk menyelenggarakan pelatihan. Strategi pembinaan melalui IHT dilakukan berdasarkan pemikiran bahwa sebagian kemampuan dalam mengembangkan kompetensi profesionalisme guru tidak harus dilakukan secara eksternal, tetapi dapat dilakukan oleh guru yang memiliki kompetensi yang belum dimiliki oleh guru lain, dengan strategi ini diharapkan dapat lebih menghemat waktu dan biaya.

Kedua, program magang, Program magang adalah pelatihan yang dilaksanakan di dunia kerja atau dunia pendidikan yang relevan dalam rangka meningkatkan kompetensi profesional guru. Program magang ini diperuntukkan bagi guru dan dapat dilakukan selama periode tertentu, misalnya, magang di madrasah tertentu untuk belajar manajemen kelas atau manajemen madrasah yang efektif. Program magang dipilih sebagai alternatif pembinaan dengan alasan bahwa keterampilan tertentu yang memerlukan pengalaman nyata.

Ketiga, program kemitraan madrasah. Pelatihan melalui kemitraan madrasah dapat dilaksanakan antara madrasah yang baik dengan yang kurang baik, antara madrasah negeri dengan madrasah swasta. Jadi, pelaksanaannya dapat dilakukan di madrasah atau di tempat mitra madrasah. Pembinaan lewat mitra madrasah diperlukan dengan alasan bahwa beberapa keunikan atau kelebihan yang dimiliki mitra, misalnya, di bidang manajemen madrasah atau manajemen kelas.

Keempat, Program pelatihan berjenjang dan pelatihan khusus. Pelatihan jenis ini dilaksanakan di lembaga-lembaga pelatihan yang diberi wewenang, di mana program disusun secara berjenjang mulai dari jenjang dasar, menengah, lanjut dan tinggi. Jenjang pelatihan disusun berdasarkan tingkat kesulitan dan jenis kompetensi. Pelatihan khusus (spesialisasi) disediakan berdasarkan kebutuhan khusus atau disebabkan adanya perkembangan baru dalam keilmuan tertentu.

Kelima, program kursus singkat di perguruan tinggi atau lembaga pendidikan lainnya, Kursus singkat dimaksudkan untuk melatih meningkatkan kemampuan guru dalam beberapa kemampuan seperti kemampuan melakukan penelitian tindakan kelas, menyusun karya ilmiah, merencanakan dan melaksanakan dan mengevaluasi pembelajaran.

Kelima, pembinaan internal oleh madrasah. Pembinaan internal ini dilaksanakan oleh kepala madrasah dan guru-guru yang memiliki kewenangan membina, melalui rapat dinas, rotasi tugas mengajar, pemberian tugas-tugas internal tambahan dan diskusi dengan rekan sejawat Program pendidikan lanjut, pembinaan profesi guru melalui pendidikan lanjut juga merupakan alternatif bagi peningkatan kualifikasi dan kompetensi guru. Pengikut 
sertaan guru dalam pendidikan lanjut ini dapat dilaksanakan dengan memberikan tugas belajar baik di dalam maupun di luar negeri bagi guru yang berprestasi. Pelaksanaan pendidikan lanjut ini akan menghasilkan guru-guru pembina yang dapat membantu guru-guru lain dalam upaya pengembangan profesi.

\section{Kegiatan IImiah Bagi Guru PAI di Kota Lhokseumawe}

Pengembangan kompetensi guru madrasah juga dapat dilakukan dengan berbagai kegiatan ilmiah lainnya bagi guru, misalnya diskusi masalah-masalah pendidikan. Diskusi ini diselenggarakan secara berkala dengan topik diskusi sesuai dengan masalah yang dialami di madrasah. Melalui diskusi berkala diharapkan para guru dapat memecahkan masalah yang dihadapi berkaitan dengan proses pembelajaran di madrasah ataupun masalah peningkatan kompetensi dan pengembangan karirnya. Program seminar, pengikutsertaan guru di dalam kegiatan seminar, dan pembinaan publikasi ilmiah juga dapat menjadi model pembinaan berkelanjutan bagi peningkatan keprofesian guru. Kegiatan ini memberikan peluang kepada guru untuk berinteraksi secara ilmiah dengan sejawat seprofesinya berkaitan dengan hal-hal terkini dalam upaya peningkatan kualitas pendidikan.

Berikutnya adalah program workshop. Workshop dilakukan untuk menghasilkan produk yang bermanfaat bagi pembelajaran, peningkatan kompetensi maupun pengembangan karirnya. Workshop dapat dilakukan misalnya dalam kegiatan menyusun kurikulum, analisis kurikulum, pengembangan silabus dan penulisan RPP. Selanjutnya program penelitian, penelitian dapat dilakukan guru dalam bentuk penelitian tindakan kelas, penelitian eksperimen ataupun jenis yang lain dalam rangka peningkatan mutu pembelajaran.

Selanjutnya pengembangan penulisan buku/bahan ajar. Bahan ajar yang ditulis guru dapat berbentuk diktat, buku pelajaran ataupun buku dalam bidang pendidikan. Pengembangan lainnya adalah pengembangan pembuatan media pembelajaran. Media pembelajaran yang dibuat guru dapat berbentuk alat peraga, alat praktikum sederhana, maupun bahan ajar elektronik atau animasi pembelajaran. Pengembangan pembuatan karya teknologi/karya seni. Karya teknologi/seni yang dibuat guru dapat berupa karya yang bermanfaat untuk masyarakat atau kegiatan pendidikan serta karya seni yang memiliki nilai estetika yang diakui oleh masyarakat.

Dalam pertumbuhan kecenderungan pendidik harus mengembangkan kompetensi profesionalnya secara mandiri. Pertama, memberikan peluang yang lebih banyak kepada guru meningkatkan pengetahuan dan keterampilan pedagogis; pemahaman budaya dan faktor-faktor psikologis yang mempengaruhi belajar siswa, dan dengan asumsi yang lebih besar, dan meningkatkan tanggung jawab mengembangkan kurikulum, penilaian, dan berkolaborasi antar guru dengan dukungan teknologi. Kedua, memberi lebih banyak waktu agar guru mengembangkan sikap baru, melakukan penilaian, berdiskusi, merenung, menilai, mencoba pendekatan baru dan mengintegrasikan mereka ke dalam pelaksanaan tugas 
sehari-hari, dan menyediakan waktu untuk merencanakan pengembangan profesi mereka sendiri. Ketiga, pengembangan profesi yang lebih mengutamakan perbaikan kerja melalui penelitian untuk menyempurnakan pekerjaan sehari-hari yang lebih efektif, memusatkan kegiatan pada aktivitas guru pada tingkat satuan pendidikan. Keempat, menyediakan pembina yang profesional yang dapat membimbing dan membantu mereka dalam meningkatkan kinerja mengajar mereka, mereka juga meningkatkan kompetensi profesional diri mereka sendiri. Kelima, melaksanakan kegiatan refleksi, sehingga monitoring proses perlu dilaksanakan secara efektif. Monitoring dapat diintegrasikan dalam sistem evaluasi diri sekolah. Dengan pengembangan sistem monitoring dan evaluasi diri proses belajar yang berkembang efektif maka tingkat kepercayaan guru pada diri mereka sendiri dalam mengajar, siswa, belajar, dan mengajar terus dapat ditumbuhkan. Keenam, mengintegrasikan guru dalam jaringan teknologi informasi dan komunikasi. Ketujuh, memantau apa yang guru lain lakukan dan guru lain hasilkan terbukti dapat meningkatkan pendidik lebih termotivatasi untuk berekesplorasi dan berinovasi dalam menyempurnakan pekerjaannya. Oleh karena itu meningkatkan kolaborasi guru dengan sekolah-sekolah yang baik di dalam negeri maupun dalam level internasional merupakan langkah yang patut mendapat pertimbangan yang serius dari para pemegang kebijakan pendidikan.

Melalui pengembangan di atas seharusnya para guru madrasah di Kota Lhokseumawe dapat mengambil bagian penting untuk tercapainya tugas dan tanggung jawabya sebagai seorang guru. Sebagai seorang guru yang memiliki banyak tanggung jawab di antaranya adalah dalam proses pembelajaran dalam menunjang pengembangan kompetensi profesionalisme berupa menguasai mata pelajaran, menggunakan metode pembelajaran agar peserta didik mudah menerima dan memahami pelajaran, melakukan evaluasi pendidikan yang dilakukan, dan menindak lanjuti hasil evaluasinya. Artinya bahwa kompetensi yang dimiliki para guru madrasah dikembangkan dengan berbagai program yang ada, maka dengan sendirinya pemenuhan kewajibannya sebagai seorang guru dapat terpenuhi dengan sendirinya. Hanya saja mampu atau tidaknya pada hakikatnya pelaksanaan pengembangan harus dilakukan sepenuh hati bukan hanya sekadar melaksanakan kegiatan, namun memiliki orientasi pengembangan untuk out put yang mampu memberikan kontribusi pengembangan kualitas pembelajaran guru dan peserta didik.

Potensi pengembangan kompetensi guru madarasah di Kota Lhokseumawe sebenarnya memiliki peluang yang cukup besar. Jumlah madrasah dan guru yang masih relatif sedikit ditambah dengan keinginan daerah atau pemerintah Aceh untuk penegakan syariat Islam tentunya menjadi alasan kuat untuk menjadikan pengembangan guru bidang studi pendidikan agama Islam sebagai salah satu wadah pendukung terlaksanaanya program tersebut. Hal ini menunjukkan bahwa bidang pendidikan dapat memberi andil besar untuk memberikan sosialisasi, pemahaman, dan pendalam pengetahuan agama kepada peserta didik, khususnya di lingkungan pendidikan.

Beberapa program madrasah dan daerah belum satu arah dalam mewujudkan tujuan 
pengembangan masyarakat yang diawali dari lingkungan madrasah sebagai generasi penerus umat. Tujuan daerah untuk melaksanakan syariat Islam di bumi Aceh seharusnya disahuti oleh lembaga pendidikan setingkat madrasah dengan berbagai pengembangan salah satunya pengembangan subjek atau pelaksana pendidikan tersebut, sehingga relevasi dan singkronisasi program pengembangan daerah dan madrasah saling mendukung antar satu dengan lainnya. Guru sebagai pelaksana pendidikan di madrasah memiliki tanggung jawab sosial untuk mengarahkan, membimbing, serta mengasuh peserta didik untuk terlaksananya nilai-nilai islami di lingkungan madrasah dan luar madrasah. Namun dengan berbagai alasan pemerintah juga harus memikirkan suplemen penting bagi guru yang melaksanakan tugas dan tanggung jawabnya yang berupa program pengembangan kompetensi guru-guru yang dimaksud.

Nasib serta keberadaan guru madrasah bidang studi rumpun pendidikan agama Islam (PAI) kurang mendapat perhatian dari pusat dengan berbagai alasan kebijakan negara, maka pemerintah daerah tidak bisa berdiam diri. Pemerintah daerah memiliki program khusus untuk tercapainya visi dan misi pengembangan daerah yang sudah barang tentu salah satu yang ikut andil adalah guru-guru pada madrasah baik tingkat madrasah ibtidaiyah, madrasah tsanawiyah, dan madrasah aliyah. Semuanya merupakan lembaga pendidikan yang dilihat dari hierarki koordinasinya keputusan, namun mereka juga merupakan aset daerah sebagai penunjang pengembangan daerah, yang tidak mungkin diabaikan keberadaan dan eksistensi mereka sebagai pendukung terlaksananya program daerah. Dengan berusaha menghilangkan kendala-kendala pengembangan kompetensi profesionalisme guru, di antaranya pelatihan guru bidang studi pendidikan agama Islam berjalan di tempat, alokasi dana peningkatan guru kurang, terjadinya penurunan motivasi pengembangan kompetensi profesionalisme guru, dan penguasaan informasi dan teknologi kurang.

Diharapkan melalui hasil penelitian ini, pemerintah daerah memiliki pemikiran yang sama dalam pengembangan lembaga pendidikan. Memberi perhatian terhadap pengembangan guru-guru madrasah sebagai cikal-bakal serta langkah awal dalam terlaksananya program daerah. Namun jika kondisi sebelumnya masih seperti semula dengan persepsi keberanaan mereka sudah ditangguhkan kepada program pusat yang selalu datang terlambat dan terbatas, maka dapat dipastikan salah satu pendukung program daerah dapat berjalan di tempat sebagaimana yang dirasakan sekarang ini. Pelaksanaan syariat Islam tidak dapat diawali dari lembaga-lembaga pendidikan Islam seperti MIN, MTs,N, dan MAN di wilayah Kota Lhokseumawe.

\section{Kesimpulan dan Saran}

Dapat disimpulkan bahwa pengembangan kompetensi guru pendidikan agama Islam di wilayah Kota Lhokseumawe di antaranya adalah pengembangan kompetensi profesionalisme guru di kota Lhokseumawe belum sepenuhnya mengalami perkembangan. Langkah-langkah pengembangan kompetensi profesionalisme guru melalui belajar mandiri, mengikuti pelatihan 
individu, diskusi dan rapat dewan guru, melakukan penguatan melalui kegiatan kerja kelompok guru/musyawarah guru bidang mata pelajaran, serta melakukan pusat kegiatan guru pada tingkat kecamatan. Sedangkan kendala-kendala pengembangan kompetensi profesionalisme guru di antaranya pelatihan guru bidang studi pendidikan agama Islam berjalan di tempat, alokasi dana peningkatan guru kurang, terjadinya penurunan motivasi pengembangan kompetensi profesionalisme guru, dan penguasaan informasi dan teknologi kurang.

Mengacu pada hasil temuan dan pembahasan, maka disarankan kepada pemangku kebijakan pendidikan di wilayah Kota Lhokseumawe untuk lebih memberikan perhatian khusus terhadap kompetensi guru Pendidikan Agama Islam, dan memberikan kesempatan untuk mengikuti pelatihan, workshop dan seminar, untuk peningkatan kompetensi guru itu sendiri. Selain itu pemerintah pusat maupun pemerintah daerah perlu mengalokasikan anggaran-anggaran dalam berbagai kegiatan dalam upaya peningkatan kompetensi guru PAI di wilayah Kota Lhokseumawe.

\section{Pustaka Acuan}

Ali, Mohamad. Pengembangan Kurikulum di Sekolah. Bandung: Sinar Baru, 1998.

Daradjat, Zakiyah. Pendidikan Islam dalam Keluarga dan Sekolah, Cet. 2. Jakarta: Ruhama, 1995.

Kunandar. Guru Profesional: Implementasi Kurikulum Tingkat Satuan Pendidkan dan Sukses dalam Sertifikasi Guru, Jakarta: RajaGrafindo Persada, 2007.

Ma'arif, Syamsul. Guru Profesional Harapan dan Kenyataan. Semarang: Need's Press, 2011.

Moleong, Lexy J. Metode Penelitian Kualitatif. Bandung: Remaja Rosdakarya, 2001.

Mulyasa. Standar Kompetensi Sertifikasi Guru. Bandung: Remaja Rosdakarya, 2007.

Naim, Ngainun. Menjadi Guru Inspiratif: Memberdayakan dan Mengubah Jalan Hidup Siswa. Yogyakarta: Pustaka Pelajar, 2009.

Ni'am, Asrorun. Membangun Profesionalitas Guru. Jakarta: eLSAS, 2006.

Novan Ardi Wiyani, Barnawi. Ilmu Pendidikan Islam. Yogyakarta: Ar-Ruzz Media, 2012.

Roestiyah. Masalah-masalah Ilmu Keguruan, Cet. 6. Jakarta: Bina Aksara,2001.

Tafsir, Ahmad. Ilmu Pendidikan Islam. Bandung: Remaja Rosdakarya, 2002.

Trianto dan Titik Triwulan Tutik. Sertifikasi Guru dan Upaya Peningkatan Kualifikasi, Kompetensi dan Kesejahteraan. Jakarta: Prestasi Pustaka Publisher, 2007.

Umardi. Pembinaan Profesionalisme Tenaga Kependidikan. Jakarta: Depdikbud Dirjen Dikti, 1999.

UU Republik Indonesia Nomor 14 Tahun 2005 tentang Guru dan Dosen.

Zainuddin, M. Pendidikan Islam dari Paradigma Klasik hingga Kontemporer. Malang: UIN Malang Press, 2009. 